\title{
Editorial
}

\section{The Conscience of Europe that Landed in Strasbourg: A Circle of Life of the European Court of Human Rights}

The European Court of Human Rights ('ECtHR' or 'Court') is the oldest and most successful regional human rights tribunal. It covers a vast territory, from Reykjavik in Iceland to Vladivostok in Russia. More than 800 million people can potentially lodge an application before the Court complaining about a violation of one of the rights enshrined in the European Convention on Human Rights ('ECHR' or 'Convention'). The ECtHR, not very modestly, calls itself the conscience of Europe. ${ }^{1}$ Admittedly, it delivers judgments that affect 47 states in many areas of law. Its case-law is discussed nationally and internationally by the general public, journalists, lawyers, academics, civil society, national (judicial) authorities, and international organisations. Although there is no consensus as to whether this Court is indeed the conscience of Europe, it does leave its footprint on the legal and social fabric of Europe.

What has puzzled us since we started researching the ECtHR quite a few years ago, is that there was no academic journal dealing exclusively with the ECtHR. Of course, a lot is written about the Court but the most authoritative articles are published in journals that are either generalist - in other words, they publish papers in all areas of law - or which specialise in areas like public international (human rights) law, European (human rights) law, constitutional law, and the theory of human rights. There was no journal devoted to the law of the ECHR that would offer researchers the opportunity to publish long, multi-disciplinary studies. Our ambition with the ECHR Law Review is to fill this gap in a way that will offer scholars a place to systematically analyse,

1 Council of Europe, The Conscience of Europe: 50 Years of the European Court of Human Rights (Millenium Publishing 2010). 
theorise, scrutinise, conceptualise, and critically evaluate the outputs of the ECtHR using a variety of theoretical lenses, methods, and academic disciplines. We hope that the journal will not only follow and reflect the practice of the ECtHR but will also influence it. Our aspiration with this new law review is not only to support the ECtHR in its everyday work, but also to contribute to the creation of a momentum of broadening and intensification around ECtHRrelated research. We would like this journal to be useful to both practitioners and academics working with the ECtHR. With this in mind, we did not only invite academics, but also (ECtHR) Judges and practicing lawyers to join our editorial and advisory boards. We are thankful to each and every member of these two boards who accepted our invitation to support this initiative.

The Court keeps providing all of us with a great deal of food for thought; hopefully, there will never be a lack of topics to discuss. Moreover, the environment within which the Court operates is constantly changing. Inevitably, the Court is changing too. These changes need to be critically assessed by the Convention commentators. This is why the outputs, policy choices, and overall function of the Court will be at the core of this new journal. That said, one might wonder whether the ECtHR deserves such attention - in other words, what is so special about the conscience of Europe that landed in Strasbourg?

Why the Court?

The ECtHR is 60 years old. During its long history it developed from a small, ${ }^{2}$ little-known institution into the most influential regional human rights court in the world. However, one might argue that most of its jurisprudential achievements have taken place during its glory years: the 8os, 9os, and early $2000 s$. Back then, the Iron Curtain had fallen and the age of human rights was upon us. The newly formed democracies wanted to (re)join Europe and the older democracies fully embraced pro-human rights rhetoric. The Court was in the centre of this bright, new world developing its case-law and promoting human rights. However, this euphoria did not last long and the tide has since turned. Enthusiasm about the ECtHR and human rights has gradually turned into human rights apathy which then changed to human rights scepticism, translated into contestation of the Court's authority. The ECtHR simply could not continue its business as usual in the circumstances, when the environment in Europe had transformed so significantly. Some commentators even argued that, currently, there is a human rights crisis in Europe. Let us give just a few

2 Both in terms of its staff and its influence. 
examples of this scepticism and defiance vis-à-vis the ECHR system, before examining what this stance might mean for the Court.

Scepticism is palpable in both 'old' and 'new' democracies. For instance, the Human Rights Act 1998 (HRA), i.e. the domestic law that gives effect to the ECHR within the United Kingdom, is the subject of constant debate. The current British government is likely to review the effects and the text of the HRA. Brexit might be followed by policies (e.g. a repeal of the HRA) that undermine the ECHR system in the UK. At the same time, the British government has repeatedly expressed its discomfort with the exercise of scrutiny by the ECtHR in cases concerning its military operations overseas and is seeking to exempt itself from such scrutiny - for instance, by derogating from the ECHR when the British military is operating overseas. British exceptionalism and Euroscepticism are at the heart of British politics now. Moving to new democracies, Poland and Hungary were success stories of democratic transition. They joined the Council of Europe fairly soon after the collapse of communism and were then admitted to the European Union. However, this fairy tale was to be short lived. Now both Hungary and Poland are known for their attacks on the judiciary, and for interferences with academic freedoms and religious rights.

Contestation and disobedience vis-à-vis the ECHR system and the Council of Europe is even more tangible in some extreme cases. Russia has never been a success story of compliance with European human rights standards. More recently Russia became emblematic of challenges that the whole European human rights project is currently facing. Occupation of the territory of another Council of Europe state, support of separatist movements, and a lack of engagement with the Council of Europe and the ECtHR are all associated with Russia. Its government compelled its way back to the exercise of full membership rights within the Council of Europe in 2018 and it is arguable that this compromise on behalf of the Council of Europe's institutions has undermined the moral foundation of the whole project.

Azerbaijan and Turkey are also among the usual suspects when it comes to weighty and systematic human rights violations. Azerbaijan has serious problems in terms of democracy and the rule of law, and tends to disregard the judgments of the ECtHR concerning core democratic rights. Azerbaijan also has the worst record of enforcement of ECtHR judgments of all 47 member states. A recent coup d'état attempt in Turkey led to a derogation from the ECHR and a wave of arrests, dismissals, and trials on very questionable grounds from the perspective of human rights.

The challenges are identifiable not only through the sheer scale of human rights scepticism in many parts of Europe, but also through certain types of human rights violations which reveal bad faith and abuse of rights on behalf of states. The Court is increasingly dealing with alleged violations of Article 18 
ECHR. These cases are an important indicator of whether systematic human rights violations exist. Moreover, if the Court finds a violation of Article 18, this means that the respondent state has intentionally violated its human rights obligations and tried to cover its traces. Every Article 18 violation should be treated as seriously as possible.

What can the ECtHR do within this new socio-political environment across Europe? More generally, what is the primary function and responsibility of the Court? How should it react to these new phenomena, especially regarding illiberalism, populism, bad faith, and Euroscepticism?

The Court has a number of options as to how to react. These options span from insisting on high human rights standards - but also risking that its standards remain ineffective, i.e. a dead letter for many states - to lowering the standards and being selective in the battles it will fight, in a way that will allow it to apply pressure only in the most outrageous situations. In between these two extremes, more options exist. More generally, the Court is called to defend the foundational principles of the ECHR and liberal democracy in a way that maintains a balance with further integration by the shaping of pan-European standards.

We felt that this new socio-political environment and the challenges ahead of the Court are the right moment to launch this journal. It is the case now more than ever that the ECHR system needs to be critically discussed and analysed. The ECHR Law Review is also a means to support the Court through these troubled times. With this in mind, we sought to identify in this very first issue of the journal the key challenges that the Court is facing, and to explore the extent to which it shall serve as a medium of European integration. To that end we invited two pairs of commentators, each of them comprising one academic and a former ECtHR Judge, to write a short note detailing these challenges. We are very thankful to Judge Angelika Nussberger and to Professor Eva Brems for sharing with us their opinion as to the challenges that the ECtHR is currently facing, and to Judge Christos Rozakis and to Dr Ed Bates who discuss the extent to which the Court should serve an integrationist role.

The Court can try to react to challenges through interpretation of the Convention and by changing its modus operandi in terms of its administrative practices and how it deals with complaints. However, this is not the only available path. The parties to the ECHR can decide to reform the Convention system. 
Since the establishment of the permanent Court in $1998^{3}$ the ECtHR is constantly being reformed. These reforms cover various aspects of the Court's functioning including its organisation structure, the length of tenure of its judges, the structure of judicial formations, and the criteria for admissibility of complaints, amongst many others. Apart from these formal amendments of the Convention though additional Protocols, ${ }^{4}$ the Court has been 'internally' reformed by means of the adoption of new editions of the Rules of Court and by changing the internal systems of case allocation. Reforming the Court is important to address the challenges it faces. Such reforms should help the Court to achieve its core aims. Yet, it is not always clear or uncontroversial what these core aims are. This inevitably affects the question of how its core aims can be achieved. If there is no clear vision as to what these aims should be, reform efforts are unlikely to be effective in the long run.

The ECHR was drafted after World War II when states realised that human rights can no longer be exclusively entrusted to sovereigns. The War and human rights abuses were intrinsically connected in the minds of the Convention drafters. For that reason, the ECHR is considered to be a means by which war between the member states might be prevented, and to offer protection from widespread human rights violations. It is also a vehicle for the integration of the national legal orders of the 47 parties in the areas of human rights, democracy, and the rule of law. The establishment of common standards across Europe is a means of integration.

At the moment, the Court arguably performs two key roles. First, it is a dispute settlement medium, i.e. it resolves human rights conflicts. The Court deals with this aim in each meritorious application, when it decides whether the rights of the applicant(s) have been violated, and what sort of remedies are required. Second, the Court's outputs, seen as an acquis, acquire a certain meta-function. By means of its judgments the Court impacts on the fabric of legal order in the respondent state as well as, more generally, on the so-called European public order.

With time, this bigger and more ambitious aim seems to have been absorbed by the rather trite conflict resolution function of the Court in the area of human rights that essentially finetunes the domestic legal systems of the ECHR parties. Moreover, the Court's attempts to be more than just an adjudicator of human rights complaints met with fierce criticism by the states. Even

3 The permanent ECtHR was established by Protocol 11 which came into force in 1998.

4 Protocol 14 entered into force in 2010, Protocol 15 is now awaiting final ratifications. Protocol 16 came into force in 2018 for the relatively small number of states that ratified it. 
without criticism, it is difficult for the Court to strategically advance its more ambitious aims because of a suboptimal machinery of execution of its judgments.

The meta-function of the ECtHR is arguably both more important and much more problematic than the one related to the adjudication of concrete cases. From a theoretical point of view, the interpretative authority developed by the Court's case-law can do a lot with only one judgment. In an ideal world, one single judgment would resolve in its entirety a particular human rights issue for all states. For that to happen conditions such as the following ones should be met. First of all, the judgment must deal with an issue capable of repeating itself in other similar cases and give a clear and authoritative resolution to the issue. Second, the respondent state should be willing to solve the problem at hand. The Court's judgment might not trigger any proper reforms and, as has been the case many times, the Court will continue accumulating applications dealing with exactly the same problem. Thirdly, the solution proposed by the Court should be realistic and executable. Fourth, other states facing similar issues should take appropriate measures to align their policies and practice with the standards set by the ECtHR. Often, these conditions are not met. Therefore, the Court is facing an avalanche of repetitive meritorious applications.

The ECtHR is designed to deal with all admissible applications that end up before it. As a result, it spends its limited resources dealing with numerous applications that do not all further its meta-function. At the same time, the Court's impact and understanding of the human rights situation in Europe is intrinsically linked with its ability to deal with human rights applications in big numbers. The reform efforts should take into account which aims are to be prioritised. This is not an easy task and various stakeholders almost inevitably see the most important aims of the Court differently. We hope that authors in the ECHR Law Review will be discussing the core aims of the Court extensively. The quality of the scholarship discussing the aims that the Court is designed to pursue is existentially important for the proper functioning of the Strasbourg system of human rights protection, its legitimacy, its sustainability, and its ability to impact on the conscience of Europe.

\section{Kanstantsin Dzehtsiarou \\ Professor in Human Rights Law, University of Liverpool \\ k.dzehtsiarou@liverpool.ac.uk}

Vassilis P Tzevelekos

Senior Lecturer in Law, University of Liverpool v.tzevelekos@liverpool.ac.uk 